\section{Basic and Applied Ecology}

www.elsevier.com/locate/baae

\title{
Contrasting predation services of predator and omnivore diversity mediated by invasive ants in a tropical agroecosystem
}

\author{
Maxime Jacquot ${ }^{\mathrm{a}, \mathrm{b}, *}$, Philippe Tixier ${ }^{\mathrm{c}, \mathrm{d}}$, Olivier Flores ${ }^{\mathrm{b}}$, David Muru ${ }^{\mathrm{a}}$, \\ François Massol $^{\mathrm{e}}$, Brice Derepas ${ }^{\mathrm{a}}$, Frédéric Chiroleu ${ }^{\mathrm{a}}$, Jean-Philippe Deguine ${ }^{\mathrm{a}}$ \\ ${ }^{a}$ CIRAD, UMR PVBMT, F-97410 Saint-Pierre, Réunion, France \\ ${ }^{\mathrm{b}}$ Université de La Réunion, UMR PVBMT, F-97410 Saint-Pierre, Réunion, France \\ ${ }^{\mathrm{C}}$ CIRAD, UPR GECO, F-34398 Montpellier Cedex 5, France \\ ${ }^{\mathrm{d}}$ CATIE, Departamento de Agricultura y Agroforesteria, 7170, Cartago, Turrialba 30501, Costa Rica \\ ${ }^{\mathrm{e}}$ CNRS, Université de Lille - Sciences et Technologies, UMR 8198 Evo-Eco-Paleo, SPICI Group, F-59655 \\ Villeneuve d'Ascq, France
}

Received 30 April 2016; accepted 13 September 2016

\begin{abstract}
Invasive natural enemies are known to either strengthen or weaken the suppression of herbivorous arthropods. However, the impact of invasive species on the predation service provided by natural enemy diversity remains largely unexplored. Here, we tease apart the roles of invasive ants as providers of a predation service and a potential disservice, i.e. reducing the diversity of natural enemies. In mango orchards on Reunion Island, we evaluated the predation service in 20 open fields by simultaneously monitoring the predation on bait eggs and arthropod communities in two strata: the ground surface and the mango tree canopy. Our results show that the predation on bait eggs was limited to the ground surface. This stratum is dominated by three invasive omnivorous ants: Pheidole megacephala and Solenopsis geminata strongly increased the predation rate of bait eggs, whereas Brachymyrmex cordemoyi was responsible for only a small decrease in predation rate. Predation rate was positively related to predator species richness, and was negatively related to omnivore species richness. The negative relationship between the predation rate and omnivore species richness is caused by the most dominant invasive ant, P. megacephala, which reduces omnivore richness and seems to strongly prey on eggs. This study demonstrates, for the first time, the distinct influence of the diversity of two trophic groups on the predation service and how these effects can be mediated by invasive ant species.
\end{abstract}

\section{Zusammenfassung}

Invasive natürliche Gegenspieler können die Kontrolle von herbivoren Arthropoden stärken, aber auch schwächen. Der Einfluss der invasiven Arten auf die Kontrollleistung der Vielfalt der natürlichen Gegenspieler ist indessen weitgehend unerforscht. Hier analysieren wir die Rolle von invasiven Ameisen als Erbringer einer Kontrollleistung aber auch als potentielle Verursacher eines Schadens durch Reduzierung der Diversität der natürlichen Gegenspieler. In Mangoplantagen auf La Réunion bestimmten wir die potentielle Kontrollleistung auf 20 Freiflächen, indem wir parallel die Abnahme von ausgelegten Fliegeneiern und die lokalen Arthropodengemeinschaften erfassten. Dies geschah sowohl auf der Bodenoberfläche als auch in den Baumkronen.

\footnotetext{
*Corresponding author at: CIRAD, UMR PVBMT, F-97410 Saint-Pierre, Réunion, France. Fax: +262 262499293.

E-mail address: jacquot.maxime.a@gmail.com (M. Jacquot).
} 
Unsere Ergebnisse zeigen, dass die Verluste an Ködereiern nur am Boden auftraten. Hier dominierten drei invasive Ameisenarten: Pheidole megacephala und Solenopsis geminata erhöhten die Abnahme der Ködereier stark, während Brachymyrmex cordemoyi eine geringe Abnahme der Prädationsrate verursachte. Die Prädationsrate war positiv mit dem Artenreichtum der Räuber korreliert und negativ mit dem der Omnivoren. Letzteres geht auf die am stärksten dominante invasive Ameise, P. megacephala, zurück, die die Artenzahl der Omnivoren stark reduziert und kräftig von den Ködereiern zu fressen scheint. Diese Untersuchung zeigt den klaren Einfluss der Diversität von zwei trophischen Gruppen auf die Kontrollleistung und wie diese Effekte durch invasive Ameisenarten beeinflusst werden können.

(C) 2016 Gesellschaft für Ökologie. Published by Elsevier GmbH. All rights reserved.

Keywords: Agroecosystem; Biological control; Biological invasion; Ecosystem service; Mango; Reunion Island

\section{Introduction}

In food webs, invasive natural enemies can strengthen or weaken the suppression of herbivorous arthropods, providing a service by feeding directly on key herbivores and/or a disservice by negatively interacting with key natural enemies of herbivores (Snyder \& Evans 2006; Crowder \& Snyder 2010). In invaded areas, invasive natural enemies not only interact with key species, but also reduce the abundance and diversity of species (Snyder \& Evans 2006; Kenis et al. 2009). Interference and exploitative competition are two main mechanisms underlying the suppression of pre-established species, especially those with similar niche requirements (Crowder \& Snyder 2010). However, few studies focus on the simultaneous effects of invasive natural enemies on herbivorous pests and on communities of natural enemies. For instance, in a California vineyard, an exotic spider increased the suppression of herbivores, while simultaneously reducing the number of native spiders (Hogg \& Daane 2011). Invasive ants can also provide services and disservices, as they are omnivorous (Holway, Lach, Suarez, Tsutsui, \& Case 2002), interact with many species, and can sometimes control herbivorous pests (Offenberg 2015). The latter effect can be complex. For instance, the imported red fire ants (Solenopsis invicta) is a direct predator of pests, but is also involved in intraguild predation, i.e. its local abundance is negatively correlated with that of natural enemies of herbivore species (Eubanks 2001). In a manipulative experiment, the introduction of a dominant invasive ant was associated with reduced species richness and evenness of the ant community, and reduced crop yield, compared with control communities or ant communities dominated by a native species (Wielgoss et al. 2014). The dominant invasive provided this disservice by increasing phytopathogen dissemination and reducing top-down control of two major pests (Wielgoss et al. 2014). Apart from these few seminal studies, the impact of invasive arthropods on the relationship between diversity of natural enemies and predation service remains largely unexplored.

Biological control of herbivorous pests by the diversity of natural enemies is a crucial service to ensure crop protection. Meta-analyses showed that the diversity of natural enemies has a generally positive effect on the suppression of herbivorous arthropods (Straub, Finke, \& Snyder 2008; Letourneau, Jedlicka, Bothwell, \& Moreno 2009) and more generally on the suppression of preys (Griffin, Byrnes, \& Cardinale 2013), but this effect can also be neutral or negative. Griffin et al. (2013) reported that diverse predator communities are not more efficient in suppressing prey than their single most efficient species. The variable effects of natural enemy diversity on herbivores can be explained by three mechanisms. Firstly, negative enemy-enemy interactions, such as mutual intraguild predation (Vance-Chalcraft, Rosenheim, Vonesh, \& Craig 2012) and interference competition (Schmitz, 2007), can reduce pest control. Secondly, higher species diversity can maintain a wider variation of phenotypic traits among enemies. This trait variability can enhance the collective performance of natural enemies through a complementarity effect, or promote the dominance of species with extreme trait values, such as species able to control particular herbivore species (selection effect) (Loreau 2000). Thirdly, interspecific facilitation of the suppression of herbivores may occur when a predator guild modifies prey behaviour, thereby facilitating capture by another predator guild (Losey \& Denno 1998, 1999). This variety of mechanisms suggests that integrative studies are needed to understand the roles of different native and invasive exotic guilds in a given agroecosystem.

The aims of the present work are: (1) to quantify the relationships between biodiversity of natural enemies and predation service in our system; and (2) to assess the role of invasive natural enemies on this biodiversity-service relationship. Our study was conducted on Reunion Island (Indian Ocean), where widespread invasive ant species are found (Blard, Dorow, \& Delabie 2003). Invasive ant species are the dominant natural enemies in our study. The study system is mango orchards (Mangifera indica L., Anacardiaceae), mangos being one of the main tropical fruit crops worldwide (FAO 2015). Among several insect pests that cause damage to mango inflorescences (Amouroux \& Normand 2013), the mango blossom gall midge, Procontarinia mangiferae (Felt), and various thrips species spend a part of their life cycle in the soil (Lewis 1997; Amouroux, Normand, Nibouche, \& Delatte 2013). It is therefore assumed that the predation service occurs in two strata: on the crop where pests feed on 
inflorescences and on the ground surface where, for some species, larvae bury and adults emerge.

To understand the effects of invasive ants on the relationship between biodiversity and predation service, we evaluated the predation service in 20 open fields by simultaneously monitoring the predation rate of bait eggs and the arthropod communities in the two strata. We then built a hierarchical Bayesian model to analyse (1) the effects of the abundance of each dominant invasive ant species, predator richness and omnivore richness on the predation service, and (2) the effect of the abundance of dominant invasive ants on the omnivore and predator richness, respectively.

\section{Materials and methods}

\section{Study area and sampling}

The study was conducted in 10 mango orchards (hereafter "sites") on the west coast of Reunion Island (Indian Ocean) belonging to the BIOPHYTO project network (www.biophyto.org). We monitored two plots at each site. In each site, there were two different farming practices between the two plots; in one plot, customary practices were used (organic or conventional), while conservation biological control practices were used in the other (ground cover, insecticide- and herbicide-free). Farming practices also varied across sites, resulting in a variety of ecological situations at plot level. The average size of plots was $1404 \mathrm{~m}^{2}$, with an average intra-site distance of $89.3 \mathrm{~m}$, and an average intersite distance of $46 \mathrm{~km}$. The field data were collected in August 2014 during the mango flowering season.

\section{Predation rate}

We used a bait-removal experiment to assess the general predation potential in our system, both on the ground surface and in the mango tree canopy. Observations of bait removal are commonly used to provide a standardized measurement of predation pressure in ecosystems (Aikens, Timms, \& Buddle 2013; Monteiro et al. 2013; Marliac et al. 2015). A bait was a card of green sand paper with eight dead eggs of the Cucurbit fruit fly (Zeugodacus cucurbitae (Coquillett)) glued on it. We did not use actual pests of mango inflorescences in order to prevent any outbreak in monitored farms. While being slightly different from pest eggs, we believe that baits are a good indicator of the predation potential since eggs of fruit flies are soft, and can be assumed to be palatable for most predator and omnivore species. These eggs were chosen for their size, similar to larvae and pupae of mango blossom gall midge and thrips species. Cucurbit fruit flies were reared on an artificial diet (CIRAD, Saint-Pierre, Reunion Island), eggs were harvested and immediately frozen at $-20^{\circ} \mathrm{C}$. Three hours later, bait egg units were prepared by gluing eight eggs on a $4 \mathrm{~cm} \times 5 \mathrm{~cm}$ card of green sand paper. The cards were kept frozen until they were placed in the plots, eggs thaws within minutes after placement. In each plot, five cards were placed in each stratum on the 13th of August, 2014 (a total of 100 egg cards per stratum). The number of bait eggs removed or damaged was recorded $24 \mathrm{~h}$ after placement in the field.

\section{Arthropod sampling}

Arthropods were sampled in three different ways. First, arthropods on the ground surface were sampled with pitfall traps. The traps (diameter: $12 \mathrm{~cm}$; depth: $11.5 \mathrm{~cm}$ ) were filled with $250 \mathrm{ml}$ of a mixture of $1: 1$ glycerine and salt water $(25 \%)$. Glass covers (diameter: $25 \mathrm{~cm}$ ) were positioned approximately $20 \mathrm{~cm}$ above the traps to keep of the rain. Eight pitfall traps were placed in each plot and left in place for one week, between the 12th and 19th of August, 2014. Second, we used suction sampling (modified leaf blower, STIHL BG56, with an oval nozzle: $14.5 \times 10 \mathrm{~cm}$ ) to sample the ground surface (with or without weeds). Suction samples were taken along transects. Transects were located between two rows of mango trees and were perpendicular to them, the length of transects was equal to the distance between rows $(6.8 \pm 1.0 \mathrm{~m})$. The total distance sampled in each plot was proportional to the size of the plot. On average, $25.3 \pm 1.1 \mathrm{~m}$ were sampled per $1000 \mathrm{~m}^{2}$, while the number of transects depended on the inter-row distance. For each transect, the number of individuals per species was calculated per metre. Third, arthropods whose habitat is the mango tree were collected using suction sampling. On each tree, a sample corresponded to suction of $1 \mathrm{~m}^{2}$ of canopy at each of the four cardinal points. The number of sampled trees was proportional to the plot area, on average $3.75 \pm 0.2$ trees per $1000 \mathrm{~m}^{2}$. Because of the distance between sites, we were only able to sample four sites a day so suction samplings were conducted between the 20th and 22nd of August, 2014.

All arthropods collected were identified to the species level (morphospecies or morphotypes). Lastly, we assigned arthropod species to trophic groups according to data from the literature (see Appendix A of Supplementary material: Tables 1 and 2 for details on predators and on omnivores). If larvae and adults have different feeding ecology, we considered the ecology of the stage sampled. In this study, we considered two trophic groups: predators, including strict predators, which feed only on other arthropods (of any trophic level), and omnivores, which feed on other arthropods and on plants (including nectar and pollen) and/or detritus.

\section{Community metrics}

Numerical dominance occurs when a species reaches greater abundance and/or biomass at baits and/or in traps than other co-occurring species (Parr \& Gibb 2010). In the present case, omnivorous species were classified as numerically dominant when they represented more than $50 \%$ of all omnivorous species in more than $10 \%$ of samples (see 
Appendix A of Supplementary material: Fig. 1). We identified dominance in two compartments: (1) the ground surface with samples taken from pitfall traps and collected by suction sampling; (2) the mango tree canopy with samples collected by suction sampling only.

For each plot, the community metrics for the ground surface were calculated using a full dataset composed of data from pitfall traps and data from suction sampling. The method consisted in randomly selecting two samples for each of the two sampling techniques to form a single subset with both types of data. This process was repeated 100 times (permutations) to form 100 subsets. For each subset, we evaluated (1) species richness with the second-order jackknife estimator, using the specpool function of R package vegan (Oksanen et al. 2015) and (2) abundance, as the sum of all arthropods in the subset. Finally we calculated the average metrics for the 100 subsets: species richness of trophic groups and abundance of dominant ant species. Exploratory trials demonstrated that the indicator values stabilised before 100 permutations. The $\mathrm{R}$ code for this procedure is provided in Appendix B of Supplementary material: 1. The community metrics in the mango tree canopy were not estimated because of the nearly total absence of predation of bait eggs in the mango tree canopy (see Appendix A of Supplementary material: Fig. 2).

\section{Model}

We built a hierarchical Bayesian model (HBM, Wikle 2003) to simultaneously test the effects of the abundance of dominant invasive ants, predator richness and omnivore richness on the predation service, and the abundance of dominant invasive ants on omnivore and predator richness. Briefly, the data was structured as follows: at each of the ten sites (noted with subscript $k$ in equations), we monitored two plots $(j)$, in each of which we obtained data on predation concerning the five bait eggs cards (i), one estimate of abundance for each dominant invasive ant species and one estimated value of species richness for each trophic group - these last two estimates coming from the combination of both suction and pitfall trap sampling.

At the first level of the HBM, we modelled the probability $\left(p_{j k}\right)$ of a bait egg on a sample card being eaten within a given plot (index $j$ ) within a given site (index $k$ ) as a function of predator species richness $\left(P_{j k}\right)$, omnivore species richness $\left(O_{j k}\right)$ and the abundance of each dominant invasive ant $\left(B c_{j k}\right.$ : Brachymyrmex cordemoyi; $\mathrm{Sg}_{j k}$ : Solenopsis geminata; $\mathrm{Pm}_{j k}$ : Pheidole megacephala), following:

$$
\begin{aligned}
& \log \operatorname{it}(p j k)=\alpha_{1}+\alpha_{2} P_{j k}+\alpha_{3} O_{j k}+\alpha_{4} B c_{j k} \\
& \quad+\alpha_{5} P m_{j k}+\alpha_{6} S g_{j k}+\xi_{1 k}
\end{aligned}
$$

where $\alpha_{1}$ is an intercept and $\alpha_{2}-\alpha_{6}$ are the effects of predator species richness, omnivore species richness and abundance of the three dominant invasive ant species respectively. $\xi_{1}$ is a random site effect accounting for variation among sites and defined as a normally distributed error $\sim N\left(0, \sigma_{1}\right)$. We used a binomial distribution to link this probability to the observed number of eaten bait eggs $\left(y_{i j k}\right)$ among the eight bait eggs on each card (index $i$ ):

$y_{i j k} \sim \operatorname{Binomial}\left(8, p_{j k}\right)$

At the second level of the model, we hypothesized that omnivore species richness $\left(O_{j k}\right)$ and predator species richness $\left(P_{j k}\right)$ within a given plot (index $\left.j\right)$ within a given site (index $k$ ) are normally distributed observations, the means of their distributions being modelled as linear combinations of the abundance of dominant invasive ants:

$$
\begin{aligned}
& O_{j k} \sim \operatorname{Normal}\left(\mu O_{j k}, \sigma^{2} O\right) \\
& \mu O_{j k}=\beta_{1}+\beta_{2} B c_{j k}+\beta_{3} P m_{j k}+\beta_{4} S g_{j k}+\xi_{2 k} \\
& P_{j k} \sim \operatorname{Normal}\left(\mu P_{j k}, \sigma^{2} P\right) \\
& \mu P_{j k}=\gamma_{1}+\gamma_{2} B c_{j k}+\gamma_{3} P m_{j k}+\gamma_{4} S g_{j k}+\xi_{3 k}
\end{aligned}
$$

where $\mu$ and $\sigma$ are the means and standard deviations and $\beta_{1}$ and $\gamma_{1}$ are intercepts, $\beta_{2}-\beta_{4}$ and $\gamma_{2}-\gamma_{4}$ are regression coefficients measuring the effects of dominant invasive ant abundance on omnivore species richness and predator species richness, respectively. $\xi_{2}$ and $\xi_{3}$ are site effects accounting for random variation among sites and defined as normally distributed errors, with a zero mean and estimated standard deviations of $\sigma_{2}$ and $\sigma_{3}$, respectively. We assigned uninformative priors to all model parameters (i.e., $\alpha_{1}-\alpha_{6}, \beta_{1}-\beta_{4}$, $\gamma_{1}-\gamma_{4}$ and $\left.\xi_{1}-\xi_{3}\right): \sim N(0,103)$.

The Metropolis-Hastings algorithm was used to simulate the posterior distributions of the model parameters. We used JAGS software (Plummer 2003) to perform Gibbs sampling and the function jags in $\mathrm{R}$ package R2jags ( $\mathrm{Su} \&$ Yajima 2012) as an interface to R. Models were run with five MCMC chains of 40,000 iterations and with a burn-in period of 20,000 runs. To monitor the convergence of MCMC chains, chain traces were inspected visually, and we checked that the potential scale reduction factor was between 1.0 and 1.1 for each parameter (Gelman \& Shirley 2011). Data used to test the above mentioned effects is presented in Appendix A of Supplementary material: Fig. 3. All the variables were standardised so that the effects could be compared directly using standardised "path" (regression) coefficients. Ant abundance values were log-transformed.

We conducted model averaging for each equation. Firstly, we ran all possible models nested within the three full models (Eqs. (1)-(3)) with all possible combinations of fixed effects (namely abundance of each dominant invasive ant, omnivore richness and predator richness) considered as explicative variables for the given equation. The possible combinations of fixed effects corresponded to equations with $0-5$ fixed effects for Eq. (1), or with 0-3 fixed effect for Eqs. (2) and (3), which results in 48 tested models. For each model, 
we obtained the deviance and the posterior distribution of parameters. Secondly, we calculated the Bayesian information criterion (BIC) and BIC weights of each model. Thirdly, we calculated the posterior mean and $95 \%$ credibility interval (CI) for each parameter, based on the overall posterior distribution of parameter, weighted by the respective BIC weight of the original models. A parameter is considered to be significantly different from zero if its weighted $95 \%$ CI does not overlap zero. We also summarised model fit at each level with a Bayesian $\mathrm{R}^{2}$ (Gelman \& Hill 2007), based on the overall posterior distribution of the response variable weighted by model BIC weight.

We used R 3.1.0 (R Development Core Team 2014) and JAGS 3.4.0 for all our analyses. The JAGS code for our complete model is given in Appendix B of Supplementary material: 2 .

\section{Results}

\section{Predation occurs at ground level}

Among all sites, predation of bait eggs on the ground surface was observed on 53 out of 100 cards initially set up. The predation rate of bait eggs in the mango canopy stratum was non-zero on only seven cards out of 100 (see Appendix A of Supplementary material: Fig. 2). In the rest of the study, we consequently focused on predation at ground level because predation in the tree canopy was virtually undetected.

\section{Communities are dominated by three ant species}

Overall, we sampled and identified 42,485 arthropods, including 63 predator species (1654 individuals) and 22 omnivorous species (19,783 individuals). Spiders were the most diverse group among all predators, with 52 different species sampled (Appendix A of Supplementary material: Table 1). Omnivores were mainly composed of insects, including 16 ant species (Appendix A of Supplementary material: Table 2). The mean species richness of omnivores and predators was lower in samples obtained by suction on the mango tree canopy than in samples obtained by suction from the ground surface (Appendix A of Supplementary material: Fig. 4). Mean abundance of both omnivores and predators was lower in samples obtained by suction on the mango tree canopy than in pitfall traps (Appendix A of Supplementary material: Fig. 4).

On the ground surface, B. cordemoyi (Forel), P. megacephala (Fabricius) and $S$. geminata (Fabricius) were identified as the numerically dominant species (see Appendix A of Supplementary material: Fig. 1). Estimated abundances of the three dominant ant species among the 10 sites are shown in Appendix A of Supplementary material: Fig. 5. Among dominant ants, $P$. megacephala was the most abundant species, and represented the numerical majority in $44 \%$

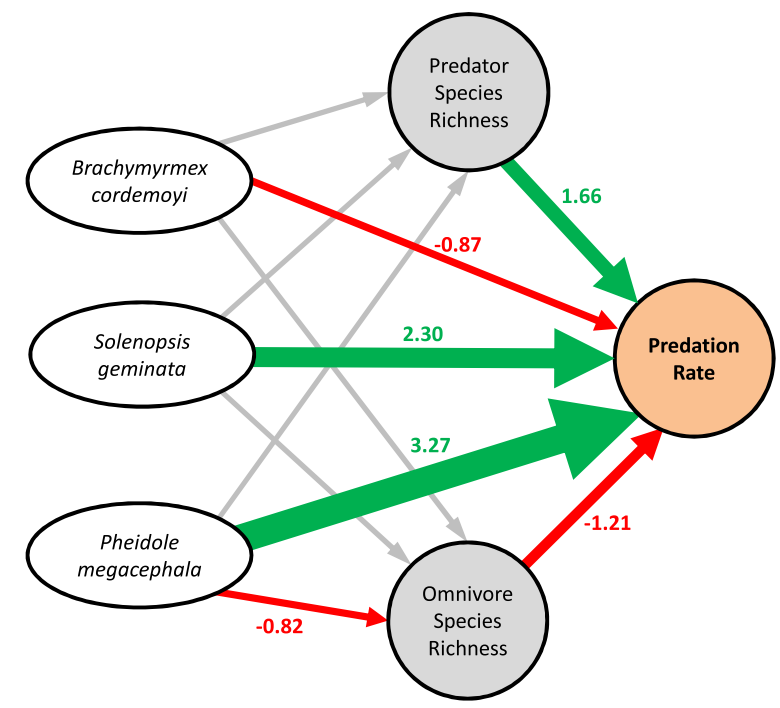

Fig. 1. Path representation of the hierarchical Bayesian model predicting the predation rate of bait eggs per plot given the abundance of each dominant invasive ant, omnivore species richness, and predator species richness (Eqs. (1)-(3)). Significant and non-significant pathways (with 95\% CI) are in colour and in grey, respectively. Green and red lines show positive and negative significant interactions, respectively. The number next to the arrows is the model-averaged standardised mean of the parameters. Model-averaged posterior mean and $95 \%$ credibility interval (CI) for all parameters as reported in Table 1. Model selection table reported in Appendix C of Supplementary material: Table 1 .

of pitfall traps and $31 \%$ of the ground surface suction samples. In the mango tree canopy, we considered that there was no dominant species, because no species showed numerical majority in a sufficient number of samples (see Appendix A of Supplementary material: Fig. 1).

\section{The three dominant omnivore ants, predator and omnivore richness affect predation rate of bait eggs}

The results for the model in Eq. (1) showed that the abundance of $P$. megacephala and $S$. geminata positively affected the predation rate (95\% CI of $\alpha_{5}$ and $\alpha_{6}: 1.28-5.07$ and 0.91-3.80, respectively, Fig. 1), whereas the abundance of B. cordemoyi negatively affected the predation rate $(95 \%$ CI of $\alpha_{4}:-1.59$ to -0.23 , Fig. 1). Predator and omnivore species richness had different effects on bait egg predation. Omnivore species richness had a negative effect on the predation rate $\left(95 \% \mathrm{CI}\right.$ of $\alpha_{3}:-2.15$ to -0.05 , Fig. 1). Although predator richness was not influenced by any dominant ant species, it positively affected the predation rate $(95 \%$ CI of $\alpha_{2}: 1.07-2.37$, Fig. 1). Site-dependent random effects also affected predation (95\% CI of $\sigma_{2}: 1.04-4.98$; Table 1 ), with effects of the same order of magnitude as those of $P$. megacephala or S. geminata. The abundance of dominant ants, omnivore richness, predator species and site-dependent ran- 
Table 1. Model-averaged mean parameter estimates and posterior distribution for the hierarchical Bayesian models (Eqs. (1)-(3)).

\begin{tabular}{|c|c|c|c|c|}
\hline Parameter & Mean & $2.5 \%$ & $50 \%$ & $97.5 \%$ \\
\hline \multicolumn{5}{|l|}{ Eq. (1) } \\
\hline Intercept $\alpha 1$ & -0.71 & -2.43 & -0.71 & 0.94 \\
\hline Effect of predator species richness on predation $\alpha 2$ & 1.66 & 1.07 & 1.64 & 2.37 \\
\hline Effect of omnivore species richness on predation $\alpha 3$ & -1.21 & -2.15 & -1.32 & -0.05 \\
\hline Effect of $B$. cordemoyi abundance on predation $\alpha 4$ & -0.87 & -1.59 & -0.86 & -0.23 \\
\hline Effect of P. megacephala abundance on predation $\alpha 5$ & 3.27 & 1.28 & 3.30 & 5.07 \\
\hline Effect of $S$. geminata abundance on predation $\alpha 6$ & 2.30 & 0.91 & 2.28 & 3.80 \\
\hline Site effect $\sigma 1$ & 2.36 & 1.04 & 2.14 & 4.98 \\
\hline \multicolumn{5}{|l|}{ Eq. (2) } \\
\hline Intercept $\beta 1$ & 0.00 & -0.61 & 0.00 & 0.62 \\
\hline Effect of $B$. cordemoyi abundance on omnivore species richness $\beta 2$ & 0.29 & -0.19 & 0.30 & 0.74 \\
\hline Effect of $P$. megacephala abundance on omnivore species richness $\beta 3$ & -0.82 & -1.77 & -0.75 & -0.19 \\
\hline Effect of $S$. geminata abundance on omnivore species richness $\beta 4$ & -0.38 & -1.18 & -0.43 & 0.57 \\
\hline Site effect $\sigma 2$ & 0.80 & 0.19 & 0.75 & 1.62 \\
\hline \multicolumn{5}{|l|}{ Eq. (3) } \\
\hline Intercept $\gamma 1$ & 0.00 & -0.60 & 0.00 & 0.61 \\
\hline Effect of $B$. cordemoyi abundance on predator species richness $\gamma 2$ & -0.08 & -0.64 & -0.08 & 0.53 \\
\hline Effect of $P$. megacephala abundance on predator species richness $\gamma 3$ & -0.32 & -0.92 & -0.35 & 0.47 \\
\hline Effect of $S$. geminata abundance on predator species richness $\gamma 4$ & 0.26 & -0.47 & 0.29 & 0.87 \\
\hline Site effect $\sigma 3$ & 0.55 & 0.03 & 0.50 & 1.43 \\
\hline
\end{tabular}

dom effects explained $99 \%$ of the variance in the predation rate of bait eggs.

\section{Omnivore species richness is negatively affected by only one dominant invasive ant species}

Model calibration allowed us to estimate the effects of invasive ant abundance on species diversity. Among the three dominant invasive ants, only the abundance of $P$. megacephala had a negative effect on omnivore species richness (95\% CI of $\beta_{3}:-1.77$ to -0.19 , Fig. 1). Site-dependent random effects also affected omnivore species richness $(95 \%$ CI of $\sigma_{2}$ : 0.19-1.62; Table 1). The abundance of dominant invasive ants and site-dependent effects explained $69 \%$ of the variance of omnivore species richness. None of the three dominant ant species affected predator species richness. Sitedependent random effects affected omnivore species richness (95\% CI of $\sigma_{3}: 0.03-1.43$; Table 1 ). Only $19 \%$ of the variance of predator species richness was explained overall.

\section{Discussion}

\section{Dominant omnivore ants affect their own trophic group}

In our system, $S$. geminata did not affect the species richness of predator or omnivore trophic groups, although $S$. geminata is known to reduce the diversity of other arthropods in areas to which it has been introduced (Wetterer 2010). This apparent lack of effect could result from mutual interference with P. megacephala (Wetterer 2010). To our knowledge, such an effect has never been reported for B. cordemoyi. Our results also showed that, on the ground surface, omnivore species richness decreased with an increase in $P$. megacephala abundance. P. megacephala, one of the world's 100 most invasive ant species (Lowe, Browne, Boudjelas, \& De Poorter 2000), is known to reduce the diversity of other arthropods in areas where it has been introduced (Kenis et al. 2009; Wetterer 2012).

By contrast, we found that no dominant ant species significantly affected predator species richness. This is consistent with the fact that invasive arthropod predators and omnivores have a strong effect only on native species with similar niche requirements (Snyder \& Evans 2006; Crowder \& Snyder 2010). In our system, invasive natural enemies were omnivorous and shared more trophic similarity with omnivores than with predators. The similarity between dominant invasive ants and omnivores was increased by the fact that ants constituted a large majority of omnivores, while predators were mainly composed of spiders. Therefore, in the omnivore trophic group, competition for food and nest sites can explain the reduction in species richness by the omnivorous ant species $P$. megacephala (Holway et al. 2002), whereas differences in niche requirements and foraging strategies between spider species and dominant invasive ants appear to allow coexistence.

\section{Dominant ants have different predatory abilities}

The abundance of dominant invasive ant species affected the predation rate of bait eggs differently. $P$. megacephala and $S$. geminata had positive effects on predation rate, consistent with their known predatory abilities (Yusa 2001; Way, 
Javier, \& Heong 2002; Dejean, Moreau, Uzac, Le Breton, \& Kenne 2007), whereas $B$. cordemoyi had a negative effect on the predation rate. Little is known about this species, which belongs to an omnivorous genus (Weiser \& Kaspari 2006). The observed negative effect may be explained by (i) interference due to competition with other ants for the exploitation of bait eggs; (ii) a low harvesting capacity of $B$. cordemoyi workers $($ size $=2.27 \pm 0.16 \mathrm{~mm})$, which are smaller than $P$. megacephala and $S$. geminata workers $(2.50 \pm 0.08$ and $3.29 \pm 0.23 \mathrm{~mm}$, respectively); and (iii) a large proportion of herbivory in the omnivorous diet of this species.

\section{Predator and omnivore species richness have contrasting effects on the predation rate of bait eggs}

On the ground surface, the predation rate of bait eggs decreased with omnivore species richness. This negative relationship was apparently caused by the most dominant invasive ant, $P$. megacephala, through a reduction in the species richness of their own trophic group and by their intense preying on bait eggs. Our results are consistent with the correlation between food resource discovery and dominance known in ant ecology (Parr \& Gibb 2012). P. megacephala is the fastest explorer and most efficient exploiter among four of the most problematic invasive ant species (not found on Reunion Island): Linepithema humile (Mayr), Lasius neglectus Van Loon et al. and Wasmannia auropunctata (Roger) (Bertelsmeier, Avril, Blight, Jourdan, \& Courchamp 2015). In addition, in this omnivore-poor community, decreasing the richness of intraguild predators could enhance bait egg removal. Indeed, one predator may be more efficient in prey suppression than multiple predators if mutual intraguild predation occurs (Vance-Chalcraft et al. 2012).

The predation rate increased with predator species richness in line with existing meta-analyses (Letourneau et al. 2009; Griffin et al. 2013). In our study, the predator trophic group is mainly composed of spiders, an order well known for its role in pest control (Marc, Canard, \& Ysnel 1999). Our results are in accordance with the literature because the abundance of spiders is known to be positively correlated with predation rate of bait eggs (Werling, Harmon, Straub, \& Gratton 2012; Mitchell, Bennett, \& Gonzalez 2014), and some spiders (including non-web- and web-building spiders) are known to prey on eggs (Pfannenstiel 2008; Morrison, Mathews, \& Leskey 2016). The predation service provided by predator diversity appeared not to be affected by the abundance of dominant invasive ants.

\section{Predation occurs at ground level}

Our results showed that predation was very low in the mango canopy. This finding is consistent with the results of Lemessa, Hambäck, and Hylander (2015), who found that the mean predation rate of caterpillars by arthropods was $1.6 \%$ on the leaves of coffee and avocado shrubs. In a temperate forest canopy, a decreasing gradient of predation pressure has been found from the understory (composed of saplings) to the upper canopy (Aikens et al. 2013). In mango systems, the low predation rate measured in the canopy can be explained by the low abundance and diversity of natural enemies in this stratum compared with the ground surface (see Appendix A of Supplementary material: Fig. 4). This difference in community composition between strata has also been observed in vineyards and apple orchards (Frank, Wratten, Sandhu, \& Shrewsbury 2007; Simon, Defrance, \& Sauphanor 2007). However, in the canopy above a vineyard, predation by key natural enemies (e.g. earwigs) compensated for the lower predator activity and species richness. Such compensating effect was not observed in the studied mango orchards.

The fact that predation was stronger on the ground surface than in the tree canopy has implications for the biological control of pests. Indeed, insect pests living only in the mango canopy or pests immigrating from the surrounding landscape will be regulated very weakly. Pests spending their pre-imaginal stage on the ground (such as the mango blossom gall midge and thrips species) can only be regulated in the long term by disrupting their life cycle. Our findings suggest that dominant invasive ants can be effective biocontrol agents. However, they can also have major negative effects. For example, S. geminata stings are very painful (Wetterer 2010) and can affect farm work. Another effect that requires evaluation is the interaction between invasive ants and honeydew-producing hemipterans (Offenberg 2015), which can facilitate the spread of both insects (Holway et al. 2002).

The methods used in the present study did not identify which species directly preyed on bait eggs. In the future, video recordings of bait prey could be used to confirm predation by dominant invasive ants and predator species. Molecular analyses of the gut contents of predators and omnivores could also be used to identify the species that prey on mango pests (Mollot et al. 2014). As ants have central-place foraging strategies (Krushelnycky, Holway, \& LeBrun 2010), resource exploitation by ants can be influenced by distance to the nests (Detrain \& Deneubourg 2009). To better understand predation in our system and to take into account the spatial variability of the community, a perspective could be to include the distance to the nests as a predictor in models. Although we showed that egg predation rate depends mainly on effects at the community level (natural enemy diversity and invasive ant abundance), the site-dependent random effect was of the same order of magnitude as any of the considered community effects. Future research should investigate which farming practices and landscape features can affect predator and omnivore species richness, and the abundance of dominant invasive ants.

In conclusion, dominant invasive ants affect the relationship between the diversity of natural enemies and the predation service. $P$. megacephala seemed to cause the negative relationship between the predation rate and omnivore species richness, through a reduction in the species richness 
of their own trophic group and, hence, in the predation of bait eggs. Predator species richness was not affected by dominant invasive ants and has a positive relationship with predation.

\section{Acknowledgements}

We thank Mickaël Tenailleau, C. Ajaguin Soleyen, M.-L. Moutoussamy, C. Baltzer and L. Müller for their assistance with data collection. We thank the following taxonomists for their assistance in species identification: J.-C. Ledoux for spiders, J.-C. Streito for Heteroptera, O. Levoux for mites, and J. Pousserau for beetles. We thank the farmers and partners of the Biophyto project, especially C. Gloanec, D. Vincenot and E. Lucas. We greatly acknowledge the Plant Protection Platform (3P, IBISA). We extend our gratitude to the Ministry of Agriculture, Food, Fisheries, Rural Affairs and Spatial Planning, which funded the Biophyto project via the Trust Account for Agricultural and Rural Development (CASDAR). We thank the Regional Council of Reunion, the Departemental Council of the Region Reunion, the European Union (ERDF, EAFRD), and the CIRAD.

\section{Appendix A. Supplementary data}

Supplementary data associated with this article can be found, in the online version, at http://dx.doi.org/10.1016/ j.baae.2016.09.005.

\section{References}

Aikens, K. R., Timms, L. L., \& Buddle, C. M. (2013). Vertical heterogeneity in predation pressure in a temperate forest canopy. PeerJ, 1, e138. http://dx.doi.org/10.7717/peerj.138

Amouroux, P., \& Normand, F. (2013). Survey of mango pests in Reunion Island, with a focus on pests affecting flowering. Acta Horticulturae, 992, 459-466.

Amouroux, P., Normand, F., Nibouche, S., \& Delatte, H. (2013). Invasive mango blossom gall midge, Procontarinia mangiferae (Felt) (Diptera: Cecidomyiidae) in Reunion Island: Ecological plasticity, permanent and structured populations. Biological Invasions, 15(8), 1677-1693. http://dx.doi.org/10.1007/s10530-012-0400-0

Bertelsmeier, C., Avril, A., Blight, O., Jourdan, H., \& Courchamp, F. (2015). Discovery-dominance trade-off among widespread invasive ant species. Ecology and Evolution, 5(13), 2673-2683. http://dx.doi.org/10.1002/ece3.1542

Blard, F., Dorow, W. H. O., \& Delabie, J. H. C. (2003). Les fourmis de l'île de la Réunion (Hymenoptera, Formicidae). Bulletin de la Société Entomologique de France, 108, 127-137.

Crowder, D. W., \& Snyder, W. E. (2010). Eating their way to the top? Mechanisms underlying the success of invasive insect generalist predators. Biological Invasions, 12(9), 2857-2876. http://dx.doi.org/10.1007/s10530-010-9733-8

Dejean, A., Moreau, C. S., Uzac, P., Le Breton, J., \& Kenne, M. (2007). The predatory behavior of Pheidole megacephala. Comptes Rendus Biologies, 330(9), 701-709. http://dx.doi.org/10.1016/j.crvi.2007.06.005
Detrain, C., \& Deneubourg, J.-L. (2009). Social cues and adaptive foraging strategies in ants. In S. Jarau, \& M. Hrncir (Eds.), Food exploitation by social insects. Florida, USA: CRC Press (p. 40).

Eubanks, M. D. (2001). Estimates of the direct and indirect effects of red imported fire ants on biological control in field crops. Biological Control, 21(1), 35-43. http://dx.doi.org/10.1006/bcon.2001.0923

Food and Agriculture Organization (2015). FAOSTAT. Retrieved from http://faostat.fao.org/.

Frank, S. D., Wratten, S. D., Sandhu, H. S., \& Shrewsbury, P. M. (2007). Video analysis to determine how habitat strata affects predator diversity and predation of Epiphyas postvittana (Lepidoptera: Tortricidae) in a vineyard. Biological Control, 41(2), 230-236. http://dx.doi.org/10.1016/j.biocontrol.2007.01.012

Gelman, A., \& Hill, J. (2007). Data analysis using regression and multilevel/hierarchical models. England: Cambridge University Press.

Gelman, A., \& Shirley, K. (2011). Inference from simulations and monitoring convergence. In S. Brooks, A. Gelman, G. L. Jones, \& X.-L. Meng (Eds.), Handbook of Markov Chain Monte Carlo (pp. 163-174). Boston: Chapman \& Hall/ CRC. http://dx.doi.org/10.1201/b10905-7

Griffin, J. N., Byrnes, J. E. K., \& Cardinale, B. J. (2013). Effects of predator richness on prey suppression: A meta-analysis. Ecology, 94(10), 2180-2187. http://dx.doi.org/10.1890/13-0179.1

Hogg, B. N., \& Daane, K. M. (2011). Diversity and invasion within a predator community: Impacts on herbivore suppression. Journal of Applied Ecology, 48(2), 453-461. http://dx.doi.org/10.1111/j.1365-2664.2010.01940.x

Holway, D. A., Lach, L., Suarez, A. V., Tsutsui, N. D., \& Case, T. J. (2002). The causes and consequences of ant invasions. Annual Review of Ecology and Systematics, 33(1), 181-233. http://dx.doi.org/10.1146/annurev.ecolsys.33.010802.150444

Kenis, M., Auger-Rozenberg, M.-A., Roques, A., Timms, L., Péré, C., Cock, M. J. W., . . \& Lopez-Vaamonde, C. (2009). Ecological effects of invasive alien insects. Biological Invasions, 11(1), 21-45. http://dx.doi.org/10.1007/s10530-008-9318-y

Krushelnycky, P. D., Holway, D. A., \& LeBrun, E. G. (2010). Invasion processes and causes of success. In L. Lach, C. L. Parr, \& K. L. Abbott (Eds.), Ant ecology (pp. 245-286). New York, USA: Oxford University Press.

Lemessa, D., Hambäck, P. A., \& Hylander, K. (2015). Arthropod but not bird predation in Ethiopian homegardens is higher in treepoor than in tree-rich landscapes. PLoS One, 10(5), e0126639. http://dx.doi.org/10.1371/journal.pone.0126639

Letourneau, D. K., Jedlicka, J. A., Bothwell, S. G., \& Moreno, C. R. (2009). Effects of natural enemy biodiversity on the suppression of arthropod herbivores in terrestrial ecosystems. Annual Review of Ecology, Evolution, and Systematics, 40(1), 573-592. http://dx.doi.org/10.1146/annurev.ecolsys.110308.120320

Lewis, T. (1997). Thrips as crop pests. England: CAB International.

Loreau, M. (2000). Biodiversity and ecosystem functioning: Recent theoretical advances. Oikos, 91(1), 3-17. http://dx.doi.org/10.1034/j.1600-0706.2000.910101.x

Losey, J. E., \& Denno, R. F. (1998). Positive predator-predator interactions: Enhanced predation rates and synergistic suppression of aphid populations. Ecology, 79(6), 2143-2152. http://dx.doi.org/10.1890/0012-9658(1998)079[2143:PPPIEP] 2.0.CO;2

Losey, J. E., \& Denno, R. F. (1999). Factors facilitating synergistic predation: The central role of 
synchrony. Ecological Applications, 9(2), 378-386. http://dx.doi.org/10.1890/1051-0761(1999)009[0378:FFSPTC] 2.0.CO;2

Lowe, S., Browne, M., Boudjelas, S., \& De Poorter, M. (2000). 100 of the world's worst invasive alien species: a selection from the global invasive species database. Auckland: The Invasive Species Specialist Group.

Marc, P., Canard, A., \& Ysnel, F. (1999). Spiders (Araneae) useful for pest limitation and bioindication. Agriculture, Ecosystems and Environment, 74(1-3), 229-273. http://dx.doi.org/10.1016/S0167-8809(99)00038-9

Marliac, G., Simon, S., Mazzia, C., Penvern, S., Lescourret, F., \& Capowiez, Y. (2015). Increased grass cover height in the alleys of apple orchards does not promote Cydia pomonella biocontrol. BioControl, 60(6), 805-815. http://dx.doi.org/10.1007/s10526-015-9687-y

Mitchell, M. G. E., Bennett, E. M., \& Gonzalez, A. (2014). Agricultural landscape structure affects arthropod diversity and arthropod-derived ecosystem services. Agriculture, Ecosystems and Environment, 192, 144-151. http://dx.doi.org/10.1016/j.agee.2014.04.015

Mollot, G., Duyck, P.-F., Lefeuvre, P., Lescourret, F., Martin, J.-F., Piry, S., \& Tixier, P. (2014). Cover cropping alters the diet of arthropods in a banana plantation: A metabarcoding approach. PLoS One, 9(4), e93740. http://dx.doi.org/10.1371/journal.pone.0093740

Monteiro, L. B., Lavigne, C., Ricci, B., Franck, P., Toubon, J.F., \& Sauphanor, B. (2013). Predation of codling moth eggs is affected by pest management practices at orchard and landscape levels. Agriculture, Ecosystems and Environment, 166, 86-93. http://dx.doi.org/10.1016/j.agee.2011.10.012

Morrison, W. R., Mathews, C. R., \& Leskey, T. C. (2016). Frequency, efficiency, and physical characteristics of predation by generalist predators of brown marmorated stink bug (Hemiptera: Pentatomidae) eggs. Biological Control, 97, 120-130. http://dx.doi.org/10.1016/j.biocontrol.2016.03.008

Offenberg, J. (2015). Ants as tools in sustainable agriculture. Journal of Applied Ecology, 52(5), 1197-1205. http://dx.doi.org/10.1111/1365-2664.12496

Oksanen, J., Blanchet, F. G., Kindt, R., Legendre, P., Minchin, P. R., O'Hara, R. B., ... \& Wagner, H. (2015). vegan: Community ecology package. CRAN R Package.

Parr, C. L., \& Gibb, H. (2010). Competition and the role of dominant ants. In L. Lach, C. L. Parr, \& K. L. Abbott (Eds.), Ant ecology (pp. 77-96). New York, USA: Oxford University Press.

Parr, C. L., \& Gibb, H. (2012). The discoverydominance trade-off is the exception, rather than the rule. Journal of Animal Ecology, 81(1), 233-241. http://dx.doi.org/10.1111/j.1365-2656.2011.01899.x

Pfannenstiel, R. S. (2008). Spider predators of lepidopteran eggs in south Texas field crops. Biological Control, 46(2), 202-208. http://dx.doi.org/10.1016/j.biocontrol.2008.03.011

Plummer, M. (2003). JAGS: A program for analysis of bayesian graphical models using gibbs sampling. JAGS: Just Another Gibbs Sampler. In Proceedings of the 3rd international workshop on distributed statistical computing (DSC 2003). ISSN 1609-395X.
R Development Core Team. (2014). R: A Language and Environment for Statistical Computing. $R$ Foundation for Statistical Computing, http://dx.doi.org/10.1038/sj.hdy.6800737

Schmitz, O. J. (2007). Concepts \& synthesis predator diversity and trophic interactions. Ecology, 88(10), 2415-2426.

Simon, S., Defrance, H., \& Sauphanor, B. (2007). Effect of codling moth management on orchard arthropods. Agriculture, Ecosystems and Environment, 122(3), 340-348. http://dx.doi.org/10.1016/j.agee.2007.01.020

Snyder, W. E., \& Evans, E. W. (2006). Ecological effects of invasive arthropod generalist predators. Annual Review of Ecology, Evolution, and Systematics, 37(1), 95-122. http://dx.doi.org/10.1146/annurev.ecolsys.37.091305.110107

Straub, C. S., Finke, D. L., \& Snyder, W. E. (2008). Are the conservation of natural enemy biodiversity and biological control compatible goals? Biological Control, 45(2), 225-237. http://dx.doi.org/10.1016/j.biocontrol.2007.05.013

Su, Y. S., \& Yajima, M. (2012). R2jags: A Package for Running jags from $R$. http://CRAN.R-Project.Org/package=R2jags.

Vance-Chalcraft, H. D., Rosenheim, J. A., Vonesh, J. R., \& Craig, W. (2012). The influence of intraguild predation on prey suppression and prey release: A meta-analysis. Ecology, 88(11), 2689-2696.

Way, M. J., Javier, G., \& Heong, K. L. (2002). The role of ants, especially the fire ant, Solenopsis geminata (Hymenoptera: Formicidae), in the biological control of tropical upland rice pests. Bulletin of Entomological Research, 92(5), 431-437. http://dx.doi.org/10.1079/ber2002185

Weiser, M. D., \& Kaspari, M. (2006). Ecological morphospace of New World ants. Ecological Entomology, 31(2), 131-142. http://dx.doi.org/10.1111/j.0307-6946.2006.00759.x

Werling, B. P., Harmon, J., Straub, C., \& Gratton, C. (2012). Influence of native North American prairie grasses on predation of an insect herbivore of potato. Biological Control, 61(1), 15-25. http://dx.doi.org/10.1016/j.biocontrol.2011.11.009

Wetterer, J. K. (2010). Worldwide spread of the tropical fire ant: Solenopsis geminata (Hymenoptera: Formicidae). Myrmecological News, 14(January), 21-35.

Wetterer, J. K. (2012). Worldwide spread of the African bigheaded ant, Pheidole megacephala (Hymenoptera: Formicidae). Myrmecological News, 17(August), 51-62. http://dx.doi.org/ 10.2984/1534-6188(2007)61[437:BAIOPI2.0.CO;2]

Wielgoss, A., Tscharntke, T., Rumede, A., Fiala, B., Seidel, H., Shahabuddin, S., \& Clough, Y. (2014). Interaction complexity matters: Disentangling services and disservices of ant communities driving yield in tropical agroecosystems. Proceedings of the Royal Society B, 281(1775), 20132144. http://dx.doi.org/10.1098/rspb.2013.2144

Wikle, C. K. (2003). Hierarchical Bayesian models for predicting the spread of ecological processes. Ecology, 84(6), 1382-1394. http://dx.doi.org/10.1890/0012-9658(2003)084[1382: HBMFPT2.0.CO;2]

Yusa, Y. (2001). Predation of eggs of the apple snail Pomacea canaliculata (Gastropoda: Ampullariidae) by fire ant Solenopsis geminata. Journal Molluscan Studies, 67(3), 275-279. http://dx.doi.org/10.1093/mollus/67.3.275

Available online at www.sciencedirect.com

\section{ScienceDirect}

